\title{
The differences of achievement of the national olympiad in chemistry at the public and private senior high school by utilizing quizizz media
}

\author{
Leony Sanga Lamsari Purba1, , Nelius Harefa ${ }^{1}$, Sali Afridika ${ }^{1}$ and Dera \\ Savera ${ }^{1}$ \\ ${ }^{1}$ Department of Chemistry Education, Faculty of Teacher Training and Education, Universitas Kristen \\ Indonesia, Jakarta 13630, Indonesia \\ *Corresponding author: LSLP, leony.purba@uki.ac.id
}

DOI: 10.24114/jpkim.v13i1.24146

Article history:

Received: 22 February 2021

Revised: 26 March 2021

Accepted: 29 March 2021

Abstract: This research is a quantitative study which aims to determine the results differences of the $2^{\text {nd }}$ National Chemistry Olympiad at the public and private senior high school using quizizz media. All participants of the population were sampled in the determination, the sampling technique used was saturated samples. The results of the prerequisite test on the data from this study showed that the data were normally and homogeneous. For normality and homogeneity tests, obtained sig $>0.05$. Data analysis using SPSS 24, carried out One Way Anova test, obtained sig.0.01 with a significance level of $5 \%$, these results indicate that there are differences in the results of the $2^{\text {nd }}$ National Chemistry Olympiad (OKN) level is low, the public high school participants results with an average score of 59.48 and private high schools with an average score of 41.95 by utilizing Quizizz media.

Keywords: Chemistry, Olympics, Learning, Quizizz

\section{Introduction}

Living in the era of the Covid-19 pandemic has not reduced the spirit of student competition in the world from various forms of schools to make achievements. This can be seen in the number of participants and countries participating in the prestigious International Chemistry Olympiad (IChO). In 2019, the number of IChO participants was 300 students from 80 countries around the world (Nan \& Zhang, 2019). Based on data obtained by Bukleski (2021), in 2020 there were only 235 students from 60 countries (Bukleski, 2021). The decrease in the number of participants from 2019 to 2020 was 65 participants and 20 countries. 
Indonesia, is not only consistent as an IChO participant in 2019 and 2020, but also consistent in making achievements. In 2019, before the Covid-19 pandemic, four Indonesian students who took part in the prestigious 51st International Chemistry Olympiad (IChO) in Paris, France, presented four medals. Two silver medals were won by students from BSMA Semesta BBS Semarang on behalf of Akuh Danang Setyo Budi and from SMAK Petra 2 Surabaya on behalf of Winston Cahya. Two bronze medals were won by students from SMAK BPK Penabur Gading Serpong on behalf of Jessica Marry Listijo and from SMAN 2 Tangerang Selatan on behalf of Bayu Dwi Putra. At the start of the Covid-19 pandemic, in 2020, Indonesian students consistently made achievements. At the $52^{\text {nd }}$ International Chemistry Olympiad (IChO) or the $52^{\text {nd }}$ International Chemistry Olympiad which was held online, four Indonesian students managed to make achievements. Two silver medals were won by Mark Susanto from SMAK BPK Penabur 1 Jakarta and Ivan Candra Gunawan from SMAK Petra 2 Surabaya, and two bronze medals were also won by Rifqi Naufal Abdjul from SMAN 81 Jakarta and Steven William from SMAK Petra 1 Surabaya (Kemdikbud, 2020).

Each year, participants who win medals at the National Science Olympiad (OSN) Chemistry will take part in three stages of the National Training Team. Pelatnas I was carried out by providing materials and tests. If they pass, then the participants are entitled to take part in training activities in the form of deepening the material and giving tests to the National Training Center II Participants who pass the National Training Center II, are entitled to take part in the National Platnas III and subsequently the results of the III National Plates will determine which participants will become representatives of Indonesia to take part in the IChO (Hakim et al. 2019).

Universitas Kristen Indonesia (UKI) has a Teaching and Education Faculty (FKIP), which consists of eight study programs. One of the study programs at FKIP UKI is the Chemistry Education study program. In the curriculum, this study program has a chemical Olympism course. With the provision of chemical olympism for one semester and the use of online chemistry learning media, the output of this course is that students are able to carry out a national chemistry Olympiad with a minimum target of 100 participants who are high school equivalent students in Indonesia (Purba, 2019).

The National Chemistry Olympiad (OKN) which was held by Chemistry Education students of FKIP UKI was already the $2^{\text {nd }}$ OKN, after the first OKN took place in 2018. This OKN is a forum for Indonesian students to grow their competitiveness and hone and channel their abilities in the field of Chemistry. The implementation of the Olympics on January 29-30, 2021, still during the Covid-19 pandemic, encourages the committee to continue to implement this OKN creatively, honestly and fairly.

By using technology (virtual laboratories) to improve student skills in the industrial field 4.0 (Panggabean et al. 2019; Namira et al. 2020; Rahman et al. 2020). UKI chemistry education students in the implementation of the Olympics are 
encouraged to take advantage of online learning media as an effort to keep up with technological developments in carrying out the Olympics in current conditions. One of the online learning media that is effectively used as an evaluation medium is the quizizz learning media (Purba, 2019). Likewise, the use of interactive quiz quizzes as a medium for evaluating on-line learning in physical chemistry 1 subjects is effective for student learning outcomes (Purba, 2020).

Another learning medium similar to quizizz is Kahoot!. Its use helps increase students' motivation to learn chemistry when applied to learning (Purba et al. 2019). However, in the implementation of this $2^{\text {nd }}$ Olympiad, the committee used quizizz because they were more accustomed to using it than kahoot. The use of quizizzes as a medium for the implementation of OKN has helped the pantia to carry out competitions by considering two things, namely speed and accuracy in processing questions (Purba, 2019). The results of the research Harefa et al. (2020), 76.32\% of students think using quizizz learning media. A study conducted by Zhao (Zhao, 2019), concluded that the use of quizizzes creates a pleasant learning atmosphere.

In competition, judgments must be fair and objective. In the implementation of this OKN, it can be ascertained that the assessment is fair and objective because the use of the quizizz application can be directly downloaded in excel form and sent to participants (Farida et al. 2020). According to Suharsono \& Uluwiyah, the use of quizizz is effective in the implementation of $\mathrm{OKN}$, considering that the millennial generation, like high school students at this time, has begun to shift to sociality 5.0 (Suharsono \& Uluwiyah, 2020). Similar to Safarati \& Rahma, quizizz educational game media was used by one of the online learning media during the Covid-19 pandemic in applied physics courses, the $2^{\text {nd }}$ OKN committee, namely Chemistry Education students, FKIP UKI also used quizizzes in the implementation of the national chemistry Olympiad (Safarati \& Rahma, 2020).

The $2^{\text {nd }}$ OKN participants were 92 people from several regions in Indonesia, such as Kalimantan, Nias, NTT, Yogyakarta, Banten, Semarang and Jakarta and its surroundings. Participants came from various private and public schools. The results of the accumulated scores of participants that have been obtained can be grouped (Noor, 2020). The grouping of values is divided into two parts, namely participants from private and state schools to study the differences in the results of their OKN, so that they may become input for stakeholders in the world of education.

\section{Methods}

This research is aquasi-experimental research, which involves three variables, namely the use of online learning media quizizz SMA Negeri and the use of online learning media quizizz SMA Private as independent variables; the results of the student national chemistry olympiad as the dependent variable. The population in this study were participants in the $2^{\text {nd }}$ national chemistry Olympiad held by Chemistry 
Education students, FKIP UKI. Because the number of participants in the $2^{\text {nd }} \mathrm{OKN}$ as a population is small, namely 92 high school students / equivalent in Indonesia, in this study all members in the population were sampled. This sampling technique is referred to as saturated sampling (Simatupang and Sormin, 2020). The research design uses a $2 \times 1$ factorial design (Ahmad, 2018), that show at Table 1.

Table 1

Research Design

\begin{tabular}{ccc} 
Utilization & $\begin{array}{c}\text { Quizizz Online Learning } \\
\text { Media at Public High } \\
\text { Schools } \\
\left(\mathrm{X}_{1}\right)\end{array}$ & $\begin{array}{c}\text { Online Learning Media Quizizz } \\
\text { in Private High School }\left(\mathrm{X}_{2}\right)\end{array}$ \\
\hline $2^{\text {nd }}$ OKN Result $(\mathrm{Y})$ & $\mathrm{X}_{1} \mathrm{Y}$ & $\mathrm{X} 2 \mathrm{Y}$ \\
\hline
\end{tabular}

Note:

$\mathrm{X}_{1}$ : A group of students from Public High Schools who take the $2^{\text {nd }} \mathrm{OKN}$ by utilizing Quizizz Online Learning Media

X2 : Groups of students from private high schools who take the $2^{\text {nd }}$ OKN by utilizing Quizizz Online Learning Media

$B: 2^{\text {nd }}$ OKN Result

$X_{1 Y}$ : Results of the $2^{\text {nd }}$ OKN of participants from Public High School students

$\mathrm{X}_{2} \mathrm{Y}$ : Results of the $2^{\text {nd }} \mathrm{OKN}$ participants from private high school students

The data collection technique in this study used a test question (Barlian, 2018) in the form of multiple choice of 40 items with 5 options for each question, namely options $A, B, C, D$ and $E$. The questions used first were validated by the expert. namely the face and content validity (Afriansyah et al. 2020) by the validator according to the field of study at the Olympics.

Table 2

Test score criteria

\begin{tabular}{c|c}
\hline Score & Category \\
\hline$<45$ & Very less \\
\hline$\geq 45-<65$ & Less \\
$\geq 65-<75$ & Enough \\
$\geq 75-<90$ & Good \\
\hline$\geq 90-<100$ & Very good \\
\hline
\end{tabular}

The data were obtained by downloading excel after all the $2^{\text {nd }}$ OKN participant students worked on the questions on the online quizizz learning media application. To test whether there are differences in the results of the National Chemistry Olympiad by utilizing online learning media for participants from public high school students and private high school students $(\mathrm{Ho}=$ No difference, $\mathrm{Ha}=$ There is $\mathrm{a}$ difference), the researcher used data analytics with inferential statistics, namely One 
Way Anova, with a level of confidence ( $p$-value) of $95 \%(\alpha=0.05)$ which was tested using the application SPSS 24. Furthermore, to see the level of ability of the students' national chemistry Olympiad results, the data were analyzed descriptively. The level of the results of the National Chemistry Olympiad refers to the test score criteria in Table 2. In accordance with the statement of Haniah (2014), to determine the spread of data distribution, whether the data spreads normally or not (Haniah, 2014).

\section{Results and Discussion}

The research data were obtained from the output of the 2nd national chemistry Olympiad held by the UKI FKIP Chemistry Education Study Program on January 2920, 2021. The data obtained were grouped into two, namely the group of participants who were students of public high schools and private high schools. The results of descriptive data processing are presented in Table 3.

Table 3

Description of research data

\begin{tabular}{|c|c|c|c|c|c|c|c|c|}
\hline & \multirow[b]{2}{*}{$\mathrm{N}$} & \multirow{2}{*}{ Mean } & \multirow{2}{*}{$\begin{array}{c}\text { Std. } \\
\text { Deviation }\end{array}$} & \multirow{2}{*}{$\begin{array}{l}\text { Std. } \\
\text { Error }\end{array}$} & \multicolumn{2}{|c|}{$\begin{array}{l}95 \% \text { Confidence } \\
\text { Interval for Mean }\end{array}$} & \multirow{2}{*}{ Minimum } & \multirow{2}{*}{ Maximum } \\
\hline & & & & & $\begin{array}{l}\text { Lower } \\
\text { Bound }\end{array}$ & $\begin{array}{l}\text { Upper } \\
\text { Bound }\end{array}$ & & \\
\hline $\begin{array}{l}\text { Public High } \\
\text { School }\end{array}$ & 45 & 59.48 & 27.45130 & 4.09220 & 51.241 & 67.7362 & .00 & 100.00 \\
\hline $\begin{array}{l}\text { Private High } \\
\text { School }\end{array}$ & 47 & 41.95 & 21.87510 & 3.19081 & 35.534 & 48.3802 & .00 & 92.00 \\
\hline Total & 92 & 50.53 & 26.15148 & 2.72648 & 45.116 & 55.9484 & .00 & 100.00 \\
\hline
\end{tabular}

A total of 45 samples from public high schools obtained an average score of OKN results 59.48 on a scale of 100 , with a minimum value of 0.00 and a maximum value of 100.The average OKN value for ampeles from private high schools, amounting to 47, is 41.95 on a scale of 100 , with a minimum value of 0.00 and a maximum value of 100.The average value for public SMA is included in the category less and for private SMA including very less category. This is an illustration of the achievements of high school students in Indonesia in the field of Chemistry. The results of the international chemistry Olympiad, which were won by student representatives from Indonesia, are a reflection of the educational conditions or competence of students in Indonesia (Kurniawati, 2014). According to him, there are public SMA OKN scores that reach the maximum score and there are also the minimum scores, the same goes for the private SMA OKN scores. It is ondepict in Fig 1.

The data to be analyzed was conducted through a prerequisite test, namely the normality and homogeneity test. The results of the normality test are presented in Table 4. 


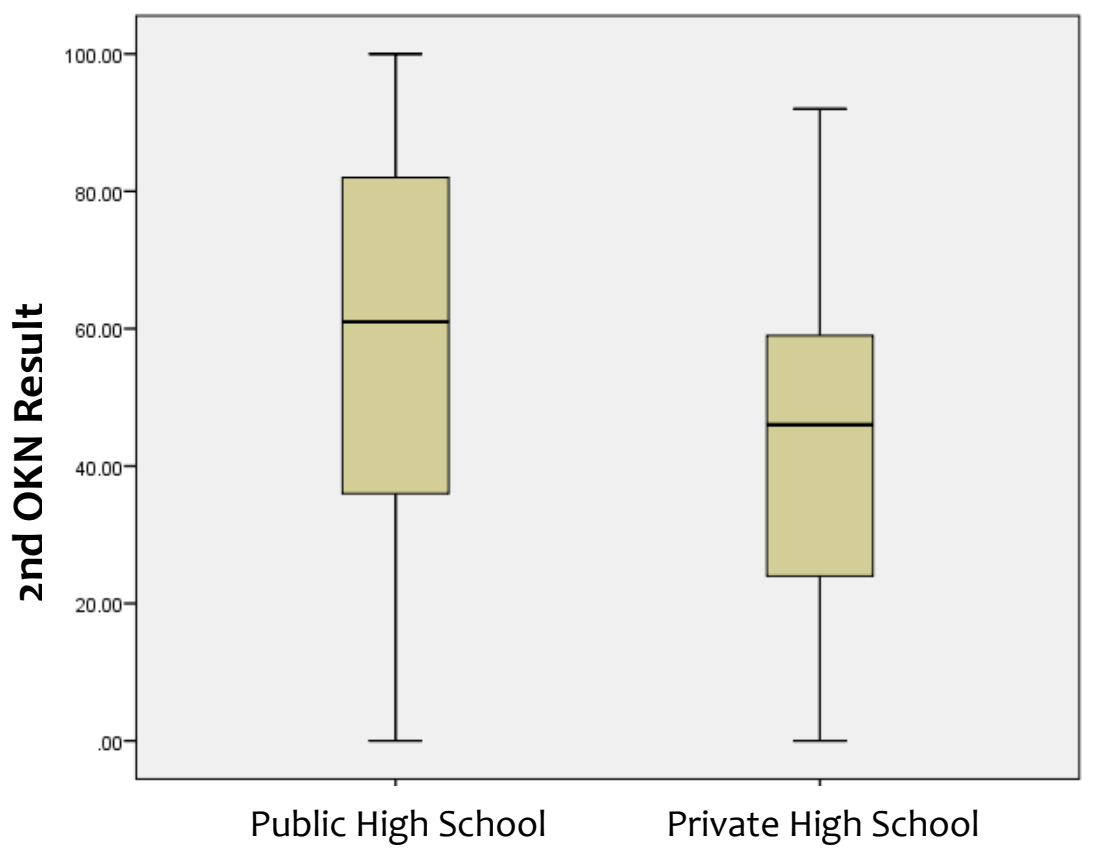

$2^{\text {nd }}$ OKN Student Participants

Fig 1. Results of the $2^{\text {nd }}$ OKN of public and private high school students

Table 4

Normality test results

\begin{tabular}{l|r|r|r}
\hline & \multicolumn{3}{|c}{ Shapiro-Wilk } \\
\cline { 2 - 4 } & Statistics & \multicolumn{1}{|c|}{ df } & \multicolumn{1}{c}{ Sig. } \\
\hline Public High School & .950 & 45 & .053 \\
\hline Private High School & .975 & 47 & .415 \\
\hline
\end{tabular}

The results of the normality test at SMA Negeri sig. 0.053 (sig > 0.05) and at private high school sig.0.415 (sig > 0.05), then the OKN result dataThis study is normally distributed. In addition to the normality test, in this study the results of the homogeneity test are presented in Table 5 .

By comparing the results of the homogeneity test with The significance level of 0.05 in this study, the result is that the research data is homogeneous. This can be seen from the results of the homogeneity test, sig. 0.059 (sig> 0.05). Furthermore, hypothesis testing is done with SPSS 24, One way ANOVA descriptive analysis. The results of hypothesis testing are presented in Table 6.

Table 5

Homogeneity test results

\begin{tabular}{c|c|c|c}
\hline $\begin{array}{c}\text { Levene } \\
\text { Statistics }\end{array}$ & df1 & df2 & Sig. \\
\hline 3.664 & 1 & 90 & .059 \\
\hline
\end{tabular}


Table 6

One way anova results

\begin{tabular}{l|c|r|r|c|c}
\hline & $\begin{array}{c}\text { Sum of } \\
\text { Squares }\end{array}$ & df & Mean Square & F & Sig. \\
\hline Between Groups & 7065.743 & 1 & 7065.743 & 11.527 & .001 \\
\hline Within Groups & 55169.159 & 90 & 612.991 & & \\
\hline Total & 62234.902 & 91 & & & \\
\hline
\end{tabular}

Based on the table above, obtained sig.001 (sig <0.05), meaning that Ho is rejected and $\mathrm{Ha}$ is accepted. Thus, the researchers concludedThere is a difference the results of the national chemistry olympiad by utilizing online learning media quizizz participants from state high school students and public high school students. The difference in OKN results is influenced by various factors both externally and internally (Setiyoningtyas, 2020). When examined further, what affects this difference is that private students who participate in the $2^{\text {nd }} \mathrm{OKN}$ come from areas that have difficulty reaching a stable internet network, while public students generally come from the surrounding Java areas that easily get a stable internet network. Thus, the researcher suggests the next researchers to focus on applying Quizizz to the learning evaluation process with a larger and more representative sample of the population.

\section{Conclusion}

Based on the results and discussion above, the researcher concluded that there were differences the results of the national chemistry olympiad by utilizing online learning media quizizz participants from state high school students and public high school students with a difference in the average score of 17.53 .

\section{Acknowledgment}

Researchers would like to thank the Universitas Kristen Indonesia for providing opportunities and funding for researchers to hold a national chemistry olympiad and evaluate the activities until they are finally compiled and published.

\section{References}

Afriansyah, E. A., Herman, T., Turmudi, T., \& Dahlan, J. A. (2020). Mendesain soal berbasis masalah untuk kemampuan berpikir kritis matematis calon guru. Mosharafa: Jurnal Pendidikan Matematika, 9(2), 239-250. DOI: 10.31980/mosharafa.vgi2.649

Ahmad, J. (2018). Desain penelitian analisis isi (Content analysis). Sekolah Pascasarjana UIN Syarif Hidayatulla

Barlian, E. (2016). Metodologi penelitian kualitatif \& kuantitatif. Padang: Sukabina Press. 
Bukleski, M. (2019). Macedonian olympic team with total of three bronze medals in the international year of the periodic table. Maced. J. Chem. Chem. Eng, 38(2),307-310.

Farida, I., Rahmawati, R., Aisyah, R., \& Helsy, I. (2020). Pembelajaran kimia sistem daring di masa pandemi Covid-19 bagi generasi Z. KTI Massa WHF Pandemi Covid-19.

Hakim, L. (2019). Chemistry olympiad questions and discussion. Lukman Hakim.

Harefa, N., Sinaga, M., \& Silaban, S. (2020). Students perception and interest on chemistry: Learning evaluation integrated media quizzes. Jurnal Pendidikan Kimia, 12 (3), 143-150. DOI: 10.24114/jpkim.v12i3.21163

Haniah, N. (2014). Uji normalitas dengan metode liliefors. (Online)

Kemdikbud (2020). https://www.kemdikbud.go.id/main/blog/2019/08/siswa-indonesia-raih-4medali-di-ollymp-kimia-internasional , accessed on 21 December 2020, 16.12 WIB

Kurniawati, M. (2014). Kajian motivasi belajar mandiri siswa melalui pembinaan dan pendampingan olimpiade sains nasional (OSN) bidang kimia pada siswa SMA. Jurnal Inspirasi Pendidikan, 4(1), 446-455. DOI: 10.21067/jip.v4i1.388

Namira, F., Azura, W., Miranda, A., Nisa, H., Silaban, S., Suyanti, R. D., \& Darmana, A. (2020). Analysis of constraints and innovation of chemistry experiment implementation in high school in Deli Serdang, Indonesia. Jurnal Pendidikan Kimia, 12(3), 106-115. DOI: 10.24114/jpkim.v12i3.21159

Nan, Z., \& Zhang, S. (2019). Theory and problems for chemistry olympiad: Challenging concepts in chemistry. World Scientific.

Noor, S. (2020). Penggunaan quizizz dalam penilaian pembelajaran pada materi ruang lingkup biologi untuk meningkatkan hasil belajar siswa kelas X. 6 SMAN 7 Banjarmasin. Jurnal Pendidikan Hayati, 6(1), 1-7.

Panggabean, F. T. M., Silaban, S., \& Simorangkir, M. (2019). Implementation of virtual lab media using problem based learning models to increase students learning achievement based STIFI and learning style test. Proceedings AISTSSE, DOI: 10.4108/eai.18-102018.2287391

Purba, LSL, Sormin, E., \& Harefa, N. (2019). Effectiveness of use of online games kahoot! chemical to improve student learning motivation. Jurnal Pendidikan Kimia, 11 (2), 57-66. DOI: 10.24114/jpkim.v11i2.14463

Purba, L. S. L. (2019). Peningkatan konsentrasi belajar mahasiswa melalui pemanfaatan evaluasi pembelajaran quizizz pada mata kuliah kimia fisika I. Jurnal Dinamika Pendidikan, 12(1), 29. DOI: 10.33541/jdp.v12i1.1028

Purba, L. S. L. (2020). The effectiveness of the quizizz interactive quiz media as an online learning evaluation of physics chemistry 1 to improve student learning outcomes. Journal of Physics: Conference Series, 1567, 022039. DOI: 10.1088/1742-6596/1567/2/022039

Rahman, G., Nasution, R. F., Lubis, A. R., Novira, P., Rahman, L., Sinaga, E. H. R., ... \& Silaban, S. (2020). Analysis of constraints and alternative solutions to the implementation of chemical practicums in several high schools in Medan. Jurnal Pendidikan Kimia, 12(1), 4451. DOl: 10.24114/jpkim.v12i1.17744

Safarati, N., \& Rahma, R. (2020). The effectiveness of online learning using quizizz education game media during the Covid-19 pandemic in applied physics courses. Indonesian Review of Physics, 3(2), 52. DOI: 10.12928/irip.v3i2.3049 
Setiyoningtyas, R., \& Kasmui, K. (2020). Pengembangan quizizz-assisted test berbasis literasi peserta didik pada materi larutan elektrolit nonelektrolit. Chemistry in Education, 9(2), 6369.

Simatupang, N.I., \& Sormin, E. (2020). The effectiveness of using flipbook maker to improve the chemistry learning outcomes of senior high school students. Jurnal Pendidikan Kimia, 12(1), 26-33. DOI: 10.24114/jpkim.v12i1.17710

Suharsono, A., \& Uluwiyah, A. (2020). Strategi Smart test dalam pembelajaran latsar CPNS di era society 5.o. PANCANAKA Jurnal Kependudukan, Keluarga, Dan Sumber Daya Manusia, 1(1), 1-9. DOI: 10.37269/pancanaka.v1i1.34

Zhao, F. (2019). Using quizizz to integrate fun multiplayer activity in the accounting classroom. International Journal of Higher Education,8 (1), 37-43. DOI: 10.5430/ijhe.v8n1p37 